\title{
Rendering peacekeeping instrumental? The Brazilian approach to United Nations peacekeeping during the Lula da Silva years (2003-2010)
}

Instrumentalizando o uso do peacekeeping? A abordagem brasileira às operações de manutenção da paz das Nações Unidas durante o governo Lula da Silva (2003-2010)

FERNANDO CAVALCANTE*

Rev. Bras. Polít. Int. 53 (2): 142-159 [2010]

\section{Introduction}

This article provides an overview of the Brazilian involvement in United Nations (UN) peacekeeping operations during the Presidency of Luis Inácio Lula da Silva (2003-2010). My purposes, however, go beyond simply describing this involvement or discussing only its arguably most important facet at the present time - the role played in the UN Stabilisation Mission in Haiti (MINUSTAH). Rather, I attempt to analyse how the Brazilian state actions and policies regarding peace operations in those eight years relate to the country's positions and attitudes towards UN peacekeeping in general. In order to provide a more comprehensive understanding of those positions and attitudes, the starting point for this article is an analysis of the Brazilian involvement in UN peacekeeping after the 1985 democratic transition, which is often acknowledged as an important event for the country's contemporary foreign policy.

In the context of the 1980s and mainly throughout the 1990s, the Brazilian decision-making elite abandoned the ideological positions that prevailed during the military regime and embraced a rather more pro-multilateral orientation aiming at the (re)integration of the country into the international system (cf. Viola, 2005; Vigevani et al., 2003; Cervo and Bueno, 2002; Bernal-Meza, 2002). ${ }^{1}$ Accordingly, one of the instruments adopted to pursue that goal was participation in peace operations (Wrobel and Herz, 2002). In the 2000s, during the eight years under Lula da Silva's government, this strategy was maintained (Vigevani and Cepaluni, 2007) and Brazil thus accepted an important military role in

\footnotetext{
* PhD candidate in International Politics and Conflict Resolution at the Centre for Social Studies - CES, University of Coimbra, Portugal (fcavalcante@ces.uc.pt).

1 These authors, however, do not agree on the courses of action adopted by Brazilian diplomacy.
} 
MINUSTAH, as well as progressively increasing its numerical participation in other UN peacekeeping missions - see Section 2 below.

By looking at that 20-year period, however, it is possible to find a number of instances in which that strategy reflected some degree of inconsistency. In fact, Brazilian participation in UN peacekeeping since 1989 has been marked by opposing, if not contradictory positions, adopted towards the establishment of UN missions in Haiti in the 1990s and in the 2000s; by a huge gap between Brazilian claims for assuming a permanent seat at the UNSC and its actual contribution to international peace and security issues throughout the 1990s; and by the vagueness of the strategic state documents released in the 1990s and in the 2000s that were supposed to lead the way to this participation.

Such inconsistencies, I argue in this article, are the product of the lack of a clear strategic direction guiding the country's participation in UN peacekeeping. In fact, the different positions and attitudes regarding UN peacekeeping in the last two decades show that Brazilian foreign policy has been unable to define exactly what to expect from its participation in UN peacekeeping, how and when to participate, under what circumstances and at what costs. In this context, the state documents that should serve as that horizon have been rather vague and implicit about the actual understanding of this instrumental use of Brazil's participation in peacekeeping activities. Accordingly, Brazilian state policies and actions concerning peacekeeping adopted under Luis Inácio Lula da Silva’s term of office - more specifically the actual participation in UN peacekeeping operations and the adoption of the Estratégia Nacional de Defesa (National Defence Strategy) - have not been able to overcome those inconsistencies and to clearly outline a strategic direction to guide the Brazilian positions and attitudes on UN peacekeeping issues. The lack of a clear direction regarding the participation in such operations may consequently hinder the country's broader foreign policy goal of playing a more active role in international peace and security issues.

To support my argument, I rely on a critical analysis of both primary official documents, as well as speeches and/or texts by Brazilian states(wo)men - and secondary sources - specialised literature. In addition, I analyse quantitative data provided by the UN Department of Peacekeeping Operations (DPKO) and the SIPRI Multilateral Peace Operations Database to obtain a clearer picture of the Brazilian involvement in UN peacekeeping operations. In order to achieve methodological coherence in the treatment of qualitative and quantitative data, all the definitions and concepts herein adopted are based on DPKO's United Nations Peace Operations: Principles and Guidelines - the so-called Capstone Doctrine. This option is intended to avoid a common conceptual confusion on the meanings and uses of terms such as 'peacekeeping', 'peace enforcement', 'peacebuilding' and 'peace operations' (see, e.g., Barnett et al., 2007; Cousens, 2001; Diehl et al., 1998). Indeed, as I discuss below in Section 2, this confusion is a remarkable feature of the Estratégia Nacional de Defesa - henceforth referred to as the Estratégia. 
Following this methodological option, peacekeeping is herein understood as a "technique designed to preserve the peace, however fragile, where fighting has been halted, and to assist in implementing agreements achieved by the peacemakers" (DPKO, 2008, p. 18). This definition reflects a rather operational character of peacekeeping and its attainment of the limited goals of keeping/maintaining a situation of negative peace, i.e. the absence of direct armed violence. ${ }^{2}$ Whereas the non-use of force, except in self-defence and defence of the mission's mandate is a principle of peacekeeping, peace enforcement "involves the application, with the authorization of the Security Council, of a range of coercive measures, including the use of military force" aiming at restoring international peace and security (ibid., p. 18). Peacebuilding, in its turn, "is a complex, long-term process of creating the necessary conditions for sustainable peace" (ibid., p. 18). Finally, peace operations are defined as "[f]ield operations deployed to prevent, manage, and/or resolve violent conflicts or reduce the risk of their recurrence" (ibid., p. 98). According to the document, therefore, 'peace operations' is a broader term referring to the wider spectrum of activities carried out by the Organisation in the realm of international peace and security: conflict prevention, peacemaking, peacekeeping, peace enforcement and peacebuilding. Due to the limited scope and length of this article, I discuss the Brazilian involvement in UN peacekeeping operations only.

The remaining of the text is organised into four sections. Firstly, I present the theoretical approach underlying the claim that peacekeeping may be used as an instrument to foster states' foreign policy goals. The next section discusses in more detail the Brazilian participation in UN peacekeeping since 1989. By focusing on both the actual Brazilian participation in UN peacekeeping operations and on the adoption of domestic policies aimed at framing peacekeeping as an instrument of foreign policy - namely the Politicas de Defesa Nacional and the Estratégia Nacional de Defesa, I show that there has been a lack of a clear definition of the goals pursued by this participation. In the third section, the absence of such a definition is illustrated by showing the Brazilian involvement in the specific case of Haiti. The section is not at all intended to be exhaustive; it simply aims to illustrate the lack of a clear strategic definition concerning the instrumental use of participation in peacekeeping operations in a specific situation. For that purpose, the case of Haiti was chosen due to its importance during Lula da Silva's Government and to the fact that successive UN peace operations have been deployed to that country since the 1990s. Finally, in the fourth section, I return to my argument and present some conclusions and limitations derived from this analysis.

2 For negative and positive peace, see Galtung (1969). The Capstone Doctrine nevertheless acknowledges that peacekeeping nowadays is not only devoted to the 'traditional' functions of observing cease-fires and separating forces between belligerent states, but it also works in actions that help to "lay the foundations for sustainable peace" (DPKO, 2008, p. 18). 


\section{Peacekeeping as an instrument of foreign policy}

Laura Neack identifies two contrasting perspectives to explain why states participate in UN peacekeeping. On the one hand, the "idealist" perspective assumes that "states will participate in UN peace-keeping [sic] out of an obligation to protect international peace and preserve international norms and values" (Neack, 1995, p. 183). The attainment of those norms and values will thus prompt states to participate in peacekeeping even when it is against their own interests. On the other hand, the "realist explanation of state participation in UN peace-keeping [sic] is that states do whatever they can, given their power resources, to protect and preserve their national interests" (ibid., p. 184). According to this explanation, participation in peacekeeping is thus understood primarily as an instrument to foster states' national interests. Writing more recently, Gegout (2009) stated that within the realist perspective, national interests are not only defined in terms of "hard" military-security issues, but also in terms of economic interests and even states' prestige. Hence, realists simply "expect governmentdefined national interest to take precedence over altruistic humanitarianism" (Gegout, 2009, p. 238).

A large number of analyses have relied on the realistic interpretation to explain the involvement of states as different as India, China and European countries in peace operations. This is evident, for instance, if one considers the diversity of the foreign policy goals usually related to their participation. From a military perspective, such goals are often associated with, among others, guaranteeing states' own security, testing operational aspects of military doctrines and strategies, forming and instructing national contingents, and/or guaranteeing their state of preparedness at comparatively low cost. Politically, the involvement in peace operations is usually attached to the goals of increasing states' international profile, acquiring prestige, guaranteeing interests in their respective areas of influence or interest, creating or strengthening a status of leadership, fostering opportunities for integration into the 'international community', and/or creating opportunities for regional/international cooperation - including military aspects (see, e.g., Gegout, 2009; Gill and Huang, 2009; Hirst and Llenderrozas, 2008; Gonnet and Hernández, 2007; Sorenson and Wood, 2005; Bergman, 2004; Krishnasamy, 2001; Bullion, 1997; Durch, 1996).

Whether explicit or not, a number of analyses of Brazilian foreign policy also adopt the realist perspective to explain the country's participation in UN peacekeeping. Wrobel and Herz (2002, p. 256), for instance, argue that the post-1985 governments adopted participation in peace operations as part of their strategy of integration into the international system. Neack (1995, p. 184) herself included Brazil in a group of Western middle-level powers that engage in peacekeeping with the purpose of finding a place within the establishment from where non-status quo interests can be pursued. Accordingly, all the situations 
in which the Brazilian military participated in UN peacekeeping were said to have occurred in a "context that confirms the effectiveness of the use of military expression as an instrument of Brazilian foreign policy" (Lannes, 1998, p. 15). ${ }^{3}$ In a comprehensive study of the Brazilian participation in UN peacekeeping, Fontoura reflects the realistic interpretation, for instance, when he states that "peacekeeping operations should be regarded by Itamaraty as an operational category of great utility for Brazilian foreign policy" (2006, p. 308; for more references, see also Fontoura, 2009; Rocha, 2009; Aguillar, 2005, 2002).

Contemporary literature on the Brazilian participation in MINUSTAH has also been supported by the same realistic perspective. In fact, a number of analysts have often associated the Brazilian engagement in Haiti to Itamaraty's alleged quest for a permanent seat at the UNSC and/or its desire to consolidate a position of leadership in Latin America (see, e.g., Burges, 2008; Vigevani and Cepaluni, 2007; Gratius, 2007; Diniz, 2006; Gauthier and Sousa, 2006). Another recent discussion within the same realistic assumption concerning the instrumental use of peacekeeping is provided by Alsina. Whilst discussing the instrumentality of military power for Brazilian foreign policy, he concluded that participating effectively in peace operations would intensify the international bargaining power of Brazil, contribute to the increase of its soft power and could be used as rationale for increasing the resources dedicated to the defence sector (Alsina Jr., 2009, p. 190).

What most of those analyses have in common is their agreement with the realist assumption that Brazilian participation in UN peacekeeping may be (and/ or should be) used to advance specific goals and in accordance with the country's national interest - which thus takes precedence over concerns of an 'idealist' nature. Hence, Brazilian participation in UN peacekeeping is often regarded as a response to the broader orientation of Brazilian guidelines at specific times. ${ }^{4}$ However, a more critical analysis of its actual participation in UN peacekeeping operations reveals that Brazilian actions have been marked by some degree of inconsistency over time, as discussed in the following section. According to the analysis proposed here, this is a consequence of the lack of a clear definition of both the parameters and the expected goals of that participation and may affect the Brazilian quest for a more active profile in international peace and security matters.

\section{The Brazilian participation in UN peacekeeping since 1989}

From a historical perspective, Brazilian involvement in peacekeeping operations is often said to be an instrument that has been used to serve the country's foreign policy goals in a coherent and continuous fashion (see, e.g., Fontoura,

3 Unless otherwise stated, all translations from Portuguese are my own.

4 A contrasting 'idealist' interpretation is provided by Seitenfus (2006a, 2006b), who relates the Brazilian involvement in MINUSTAH to his concept of diplomacia solidária. According to him, this participation is "solely guided by a duty of conscience" (Seitenfus, 2006a, p. 8). 
2009, 2006; Aguillar, 2005, 2002; Lannes, 1998; Cardoso, 1998). This becomes more evident in the words of Sérgio Aguillar, a former military observer in the UN Transitional Authority in Eastern Slavonia, Baranja and Western Sirmium (UNTAES). Writing in 2002, he affirmed that "[f]or over fifty years this participation has served to project Brazil, within the framework of such organs [referring to the UN and the Organisation of American States (OAS)], as a country acting for the benefit of peace, coherently with our foreign policy and in accordance with our constitutional principles" (Aguillar, 2002, p. 364).

More critical analyses nevertheless reveal that this involvement has actually been marked by some degree of inconsistency and incoherence. Diniz (2005, p. 101), for instance, refers to the different positions taken by Brazilian diplomacy when voting for the UN missions to Haiti authorised under Chapter VII: the country abstained from voting for Resolution 940 (1994), but favoured the adoption of Resolution 1,542 (2004). Rocha, in turn, refers to the Brazilian state's contradictory position of defining its area of strategic interest as South America and the South Atlantic, while at the same time deploying military personnel to the Caribbean (Rocha, 2009; note 25).

In this section, which is not intended to be exhaustive, ${ }^{5} \mathrm{I}$ review some of those inconsistencies since 1989 by analysing the actual Brazilian participation in UN peacekeeping and the policies adopted at the domestic level related to that matter.

\section{Antecedents}

Brazilian involvement in UN peace operation dates back to 1956, when the country sent an infantry battalion to the First UN Emergency Force (UNEF I), which operated in the Sinai Peninsula from 1956 to $1967 .{ }^{6}$ In the following years, Brazil would also engage in missions in the Congo (ONUC), Western Guinea (UNSF), Cyprus (UNFICYP), the Dominican Republic (DOMREP) and IndiaPakistan (UNIPOM). ${ }^{7}$ Throughout this period, in numerical terms, Brazil had a timid, though quite regular participation in UN peacekeeping operations, with UNEF I as a clear exception - the country sent a reasonably large contingent and contributed with two Force Commanders. ${ }^{8}$

From 1968 onwards, however, Brazilian diplomacy would be much influenced by Araújo Castro, who contended that international organisations

5 See the references provided in the previous section for more comprehensive reviews.

6 DPKO does not account the UN Special Committee on the Balkans (UNSCOB) as one of its peacekeeping operations. Hence, following the methodological option of adopting DPKO definitions and figures, the Brazilian involvement in that mission is not taken into account in this article.

7 This means that Brazil participated in six out of the ten peacekeeping operations established by the UN between 1948 and 1972 .

8 Brazil sent a total amount of 6,300 military troops to the Middle East from 1957 to 1967 (Aguillar, 2002, p. 367). Two Brazilians Major-Generals served as Force Commanders of UNEF I: Carlos F. Paiva Chaves (between January and August 1964) and Syseno Sarmento (January 1965-January 1966). See also DPKO (2010b). 
(such as the UN itself) and treaties (such as the Treaty for the Non-proliferation of Nuclear Weapons, NPT) were used by the great powers as instruments of a "policy of freezing the world power structure" (Araújo Castro, 1972, p. 159). Brazil would thus adopt a posture of distancing itself from multilateral forums. Hence, during this period, not only would Brazil cease its contribution to UN peacekeeping operations, but it would also avoid discussing the issue by not assuming non-permanent seats at the UNSC after 1968 and by abandoning the UN Special Committee on Peacekeeping Operations in 1977.' Some analysts have referred to such attitudes as part of a strategy defined as "autonomy through distance" (Vigevani and Cepaluni, 2007; Vigevani et al., 2003; Fonseca Jr., 1998).

\section{Return to action, 1989-2002}

In the period from 1988 to 2002, the UN established 42 peacekeeping operations, of which Brazil participated in $19 .{ }^{10}$ As in the period from 1956 to 1967 , Brazil's contribution of personnel continued to be very restricted in number - the exception is the total contribution of more than 4,000 military personnel from 1995 to 1997 to UNAVEM III in Angola (see SIPRI, 2010; Aguillar, 2002, pp. 375-396; Wrobel and Herz, 2002, pp. 304-308).

From 1989 onwards Brazil would once again participate in peacekeeping operations as a consequence of two main factors. On the one hand, during the 1990s the Brazilian decision-making elite gradually changed its perception about the international scenario, thus contributing to a re-orientation of Brazilian foreign policy towards conformity with international norms and rules - hence the progressive abandonment of the prevailing ideological postures during the military regime and the adoption of discourses favouring multilateralism (Wrobel and Herz, 2002). As a consequence, "the elected governments have pursued a strategy of insertion that involved the acceptance of international regimes, a greater participation in UN peace operations and the quest for regional stability, which opposed the sub-regional competition of the previous period" (ibid., p. 256). Vigevani and others define this re-orientation in terms of a strategic change from the quest for "autonomy through distance" to one of "autonomy through participation" (Vigevani and Cepaluni, 2007; Vigevani et al., 2003).

On the other hand, the diversification of peacekeeping operations in the late1980 s meant that their character ceased to be overwhelmingly military and started

9 Brazil did not participate in any of the three peacekeeping operations established during this period: UNEF II, UNDOF and UNIFIL (see DPKO, 2010b). After concluding its 1967-1968 mandate, Brazil would only take a non-permanent seat on the UNSC again in 1988.

10 UNAVEM I, II, III and MONUA (Angola), ONUCA (Central America), ONUSAL (El Salvador), UNPROFOR, UNCRO, UNPREDEP, UNTAES, UNMOP (in countries of the former Yugoslavia), UNTAC (Cambodia), ONUMOZ (Mozambique), UNOMUR (Uganda-Rwanda), UNOMIL (Liberia), UNAMIR (Rwanda), MINUGUA (Guatamala), UNTAET and UNMISET (Timor-Leste) (see DPKO, 2010b; SIPRI, 2010). Brazilian participation in UNFICYP after 1995, in partnership with Argentina (see Wrobel and Herz, 2002, p. 304-308; Aguillar, 2002, p. 374-375), is not listed in this figure since the mission was established in 1964. 
to include civilian components to carry out activities such as the monitoring of elections and judicial reform. ${ }^{11}$ Alongside the broader re-orientation of Brazilian foreign policy towards multilateralism, the diversification of peacekeeping activities had an important impact in defining the character of the Brazilian return to such operations because it allowed for the participation of other sectors of society, as reflected in the composition of the Brazilian personnel in UN operations in the 1990s. In fact, during this period the Brazilian contribution included not only military, but also police personnel, medical teams and civilian electoral observers (see SIPRI, 2010; Aguillar, 2002, pp. 375-396; Wrobel and Herz, 2002, pp. 304-308).

In the 1990s, Brazil adopted a number of political-institutional measures that would potentially support its engagement with peacekeeping based on a strategic relationship between participation in peacekeeping and the country's national interest. These measures, more specifically, were the adoption of the Politica de Defesa Nacional (Brazil, 1996) and the subsequent creation of a unified Ministry of Defence. The National Defence document set out the principles and guidelines for the conduct of national strategic affairs, taking into consideration Brazil's peaceful tradition and the absence of visible external threats in South America (Brazil, 1996, Section 2). This re-orientation of the national interest was reflected in the PDN, which clearly reinforced a posture that abandoned the prevailing ideological commitments of the previous period of "autonomy through distance". Indeed, the document states that one of the goals of national defence is "the projection of Brazil in the concert of nations and its greater integration into the international decision-making process" (ibid., para. 3.3.f). Following suit, "participat[ing] in international peacekeeping operations, in accordance to the national interests" figured within the general strategic guiding lines of the document (ibid., para. 4.e).

The creation of the Ministry of Defence in 1997, on the other hand, had a political and a military significance, according to Wrobel and Herz (2002, p. 288-293). The former related to a greater institutionalisation of the Armed Forces in the newly re-established democracy, since the Minister himself would be a civilian directly connected to the President and would assume the command of the three Forces, which would be unified from that moment onwards. The latter referred to the potential improvement in coordination between the Army, the Navy and the Air Force, greater possibility of carrying out joint operations, and a greater facility to distribute security and defence resources.

Notwithstanding, the Brazilian practice was rather different from its discourse and the domestic institutional changes adopted, since its hesitant

11 Indeed, peacekeeping operations started to progressively undertake actions that would later be understood as pertaining to the realm of peacebuilding, which thus led some authors to classify peacekeeping operations as 'multidimensional' and 'multidisciplinary', or in terms of 'second' and 'third generation' (see, e.g., Diehl, 2008; Fontoura, 2006; Bellamy et al., 2004; Durch, 1993). 
participation in UN peacekeeping, both in terms of operations and in numbers of personnel, contrasted with the overt campaign to take a permanent seat on the UNSC during the 1990s. Two complementary explanations can thus be outlined to justify this contrast. First, the fragility of the new Ministry of Defence, which pointed to the superficiality of the politico-institutional arrangement that was obtained at the time (see Zaverucha, 2005), and which thus had an unfavourable impact on Brazil's domestic capabilities to participate in UN peacekeeping. Second, the PDN contained a political vagueness that was not clear enough to direct Brazilian efforts abroad. After noting that Brazil takes part of peace operations as a contribution to international peace and security (see Brazil, 1996; para. 4.12), the document states that:

In order to expand the country's projection onto the world stage and reaffirm its commitment to the defence of peace and to cooperation among peoples, Brazil should intensify its participation in humanitarian actions and in peace missions under the aegis of multilateral organs. (ibid.; para. 6.17)

However, although stating that such participation should be in accordance with the "national interest" (ibid.; para. 7.1.XXV), the document does not state under which conditions this participation should take place, the concrete limits of the Brazilian participation or until when it should participate in different situations. In fact, the susceptibility of the document to the contradictory positions of Brazilian diplomacy and the military sector - certainly one of the causes of the vagueness of the document - has led a scholar to refer to it as a "masterpiece of political ambiguity" (Cervo, 2002, p. 354).

\section{Participation in UN peacekeeping during Luis Inácio Lula da Silva's tenure in office, 2003-2010}

Since 2003, Brazil has participated in six out of the eight peacekeeping operations established by the United Nations during this period. ${ }^{12}$ The year 2004 represented a rupture with the previous tendency of timid contribution. In fact, when Luis Inácio Lula da Silva took over the Presidency in January 2003, there were 79 persons deployed in two UN missions, 76 of them serving in TimorLeste (DPKO, 2003). By contrast, as of May 2010, according to DPKO (2010a) figures, Brazil was involved in nine peacekeeping operations, with 2,246 persons

12 The peacekeeping operations established since 2003 are: UNMIL (Liberia), UNOCI (Côte d'Ivoire), MINUSTAH (Haiti), ONUB (Burundi), UNMIS (Sudan), UNMIT (Timor-Leste), UNAMID (SudanDarfur), MINURCAT (Central African Republic-Chad). Brazil participated in all these missions except ONUB and UNAMID. During the period 2003-2010, Brazil also contributed to MINURSO (since 2007) and UNMEE (from 2006 to 2008), but these participations are not included in this account since the missions were established, respectively, in 1991 and 2000 - hence, before the beginning of Lula da Silva's government. See DPKO (2010b) and SIPRI (2010). 
deployed (2,244 males and 2 females) playing military, police and civilian roles. MINUSTAH clearly represents the overwhelming majority of this efforts $(2,191$ persons), not only by reason of the surge in contribution of personnel after the earthquake that hit the country in January 2010, but also because of the key role played by Brazil in this mission. The significance of Brazilian involvement in MINUSTAH, however, is not only a question of numbers, for its participation might have had an important effect in influencing the country's involvement in other peacekeeping missions - a hypothesis that should be put to test in future research.

In this period, the main guiding lines of Brazilian foreign policy suffered no change. Indeed, drawing on Hermann's model of foreign policy change, Vigevani and Cepaluni (2007) argue that the main differences between Inácio Lula da Silva's foreign policy and that carried out by Fernando Henrique Cardoso (1994-2002) are only in the realm of adjustment and programme changes. The main guidelines of Brazilian foreign policy, such as the overall goal of economic development and external political autonomy, these writers state, were not altered (Vigevani and Cepaluni, 2007, p. 275, also 284-292).

Hence, it is feasible to state that the participation in UN peacekeeping continued to be understood by foreign policy decision-makers as an instrument to foster specific Brazilian goals. In fact, the role played in Haiti is often understood as part of a broader strategy aiming at the promotion of international peace and that would strengthen Brazil's international profile abroad - a strategy well captured by Vigevani and Cepaluni's concept of "autonomy through diversification" (ibid., p. 303-304). Among the benefits of this participation, Vegevani and Cepaluni mention raising the country's profile in preparation for an eventual permanent seat on the UNSC and the "international acknowledgement necessary for a middle power" (ibid., p. 304).

Apart from the involvement in MINUSTAH and the increased participation in the number of other UN peacekeeping missions, Brazil also went through important political-institutional developments in terms of peacekeeping. The first was the update of the 1996 Politica de Defesa Nacional, which was carried out in 2005. The new text, which acknowledged some of the changes that affect the internal and external contexts to which Brazil belonged, reaffirmed the quest for the peaceful settlement of controversies and the strengthening of international peace and security - both were thus established as goals of the National Defence Policy (see Brazil, 2005). Taking a further step, Lula released the Estratégia Nacional de Defesa in 2008, a very ambitious plan designed to achieve improved articulation between the national defence and foreign policies. In this document, participation in peace operations was included as a strategic action, and it thus established as a goal "promoting the increase in training and in participation of the Armed Forces in peace operations, joining peace forces established by the UN or by regional multilateral organs" (Brazil, 2008, p. 62). 
Under Luis Inácio Lula da Silva’s Presidency, therefore, Brazilian diplomacy would consolidate the broader national strategy of international insertion forged during the 1990s, as discussed by Vigevani and Cepaluni (2007). According to the analysis proposed here, when it comes to matters related to peacekeeping this consolidation is reflected in at least two aspects. The first refers to the clear relationships established between the use of national defence capacities as an instrument of foreign policy in matters related to peacekeeping, which thus reflects an attempt to establish an improved articulation between national defence and foreign policies. The second aspect refers to the attitude of indeed assuming greater responsibilities in international peace and security issues, namely by participating in more UN peacekeeping operations and accepting a more prominent role in MINUSTAH.

However, the policies adopted during Luis Inácio da Silva’s tenure were not bold or clear enough to overcome the identified lack of understanding concerning the instrumental use of peacekeeping as a tool of Brazilian foreign policy that had prevailed since 1989. Indeed, a more detailed analysis of either the updated version of the Politica de Defesa Nacional or the Estratégia reveals that both documents are still marked by the same vagueness of the 1996 PDN.

Consider, for instance the most recent Estratégia. The $19^{\text {th }}$ guideline of the document is "[to] prepare the Armed Forces to undertake increasing responsibilities in peacekeeping operations" (Brazil, 2008, p. 17; my emphasis). In the rest of the document, however, the term "peacekeeping operations" (operaçôes de manutenção $d a p a z)$ is replaced by "peace operations" (operaçôes de paz). For example: the document presents one of the strategic actions that should guide the implementation of Estratégia as "[to] promote the increase of instruction and participation of the Armed Forces in peace operations" (ibid., p. 62; my emphasis). Adding to the confusion, when referring to the Navy, the document adopts the term "international peace operations" (operaçôes de paz internacionais), which may also lead to some confusion for those familiar with the term "naval peacekeeping" (see Staley, 1992). Strikingly, albeit symptomatic of its vagueness, the document neither defines those terms, nor attempts to distinguish between their meanings, nor does it refer to the usages and concepts adopted by any "multilateral organ". Furthermore, the Estratégia still contained the same gaps as the previous Politica de Defesa Nacional and did not refer to what conditions Brazilian participation should take place in, the concrete limits of the Brazilian participation or until when participation in different situations should last.

\section{The Brazilian involvement in Haiti}

Rather than describing exhaustively the Brazilian involvement in MINUSTAH, this section looks at some aspects of the Brazilian discourse-action nexus on the case of Haiti in the past two decades or so. By doing so, I expect to illustrate my argument in a specific situation, thus highlighting the point 
that the inconsistencies of the Brazilian attitudes and positions regarding UN peacekeeping reflect the lack of a clearly defined strategy to guide the country's participation in those actions.

\section{Then...}

From the previous overview of Brazilian participation in UN peacekeeping, it is clear that Brazil did not participate in any of the UN missions deployed to Haiti throughout the 1990s: UNMIH (1993-1996), UNSMIH (1996-1997), UNTMIH (1997) and MIPONUH (1997-2000). As well as not participating in those missions, as a non-permanent member of the UNSC in 1993-1994, Brazil actually abstained from voting on some important resolutions concerning the case of Haiti, as noted by Diniz (2005, p. 101). In fact, after voting in favour of the establishment of UNMIH and two subsequent mandate expansions (see UNSC, 1993, 1994a, 1994b), Brazil abstained from voting for Resolution 940, which authorised the formation of a multinational force to "facilitate the departure from Haiti of the military leadership" and the "prompt return of the legitimately elected President” Jean-Bertrand Aristide (UNSC, 1994d, op. 4).

The decision to abstain from voting is often justified based on Itamaraty's resistance to operations authorised under Chapter VII (see Diniz, 2005, p. 101; Wrobel and Herz, 2002, p. 309-312). According to Diniz (2005, p. 95), this position reflects the concern that such operations could possibly be used as instruments by the great powers to intervene in the domestic affairs of other countries. This concern is indeed reflected in the Brazilian justification given at the UNSC before abstaining from voting for Resolution 940: the Brazilian representative referred to the non-intervention principle expressed in the country's constitution and in the OAS Charter (see UNSC, 1994c, p. 9). This is even more explicit in the statement by the then Minister of External Relations, Celso Amorin, also before the UNSC:

The seriousness of the Haitian crisis requires the continued attention of the international community, but, as we have expressed on several occasions, we believe that any action to be taken should be completely in accordance with the Charter of the United Nations and of the Organisation of American States, especially in matters concerning the basic principle of non-intervention. $[\ldots]$

Naturally, my country will not fail to support the democratic reconstruction of Haiti, with complete respect for its sovereignty and in accordance with the principles of non-intervention and self-determination. (Amorim, 1994, pp. 17-18)

Throughout the 1990s, therefore, Brazilian discourse supported the traditional principle of non-intervention and thus the country decided not to participate in the successive UN peace operations deployed to Haiti. 


\section{... and now (since 2003)}

A few years later, Brazilian discourse and actions would be different from those expressed throughout the 1990s. After voting for the approval of a multinational force authorised under Chapter VII (see UNSC, 2004), the country participated in the UN mission subsequently deployed to Haiti - also authorised under Chapter VII with regard to its security mandate - and adopted a discourse that sought to link its role in Haiti to demands related to social justice. In fact, since 2004, not only has Brazil been one of the major troop-contributing countries of the Mission, but it has also contributed six military officers to the post of MINUSTAH's Force Commander (see DPKO, 2010b).

The Brazilian discourse concerning the UN peacekeeping mission in Haiti has also changed. During Luis Inácio Lula da Silva's administration, Brazil sought to avoid the question of non-intervention that had marked its diplomatic discourse in the previous decade. Rather, Brazil under Lula da Silva developed a discourse of support to Haiti's stabilisation that was based not only on militarysecurity concerns, but also on problems such as "poverty" and "social injustice" (Amorim, 2006) and objectives such as the "consolidation of democracy and development" (Amorim, 2007) and "social justice" (Amorim, 2004). The Brazilian involvement in Haiti, therefore, was related to a matter of "promotion of equitable development" (da Silva, 2004b, p. 3) and to its "commitment to peace and development of a brother country” (da Silva, 2004a).

In contrast to the previous decade, therefore, Brazil favoured and supported the deployment of a UN peacekeeping mission in Haiti that was authorised under Chapter VII when carrying out its mandate in the area of security, besides adopting a discourse that sought to avoid references to the traditional principle of non-intervention. It thus becomes very clear that different discourses and actions were adopted by Brazil in a relatively short period of time. This indicates, according to the analysis herein proposed, the lack of a strategic understanding about how the country's participation in UN peacekeeping could be used as an instrument of foreign policy.

\section{Rendering peacekeeping instrumental?}

In the eight years of the Lula da Silva Government (2003-2010), Brazil's participation in UN peacekeeping has been marked by the key role played by the country in Haiti and by its increased participation in other UN peacekeeping operations. However, as discussed in Section 3, this involvement clearly contrasted with the positions fostered by Brazilian diplomacy in the 1990s, when the country stood against the deployment of a mission to Haiti authorised by the UNSC under Chapter VII. Based on this illustration, and on a previous discussion of the general involvement of Brazil in UN peacekeeping since 1989, it has been 
possible to verify that, although supposedly based on the realistic understanding that participation in peace operations may foster states' national interests, Brazil has not yet defined a clear direction to guide its positions and attitudes on this matter.

Some might say that this is indeed a deliberate strategy and that participating in UN peacekeeping operations on a case-by-case basis is indeed in Brazil's national interest. However, this interpretation is misleading. In fact, as noted by Diniz (2005, p. 99-100), the Brazilian bid for a permanent seat on the UNSC, for instance, was threatened by the country's scarce participation in UN peace operations and hence Brazil had to accept the call to join MINUSTAH. Considering this reasoning, and bearing in mind the current status of an emerging power that has recently been attributed to Brazil (see, e.g., Burges, 2008), it seems likely that the maintenance of such inconsistent positions in the realm of international security may have a negative impact on Brazil's 'emergence'.

Although the publication of the Estratégia signals an important step in forging an understanding on the part of the state on how the participation in UN peacekeeping could be used as an instrument of foreign policy, several questions remain unanswered: under what circumstances should Brazil participate in UN peace operations? What role is the country willing to assume in different circumstances? Until when? At what costs? Also, as pointed out in in Section 2 , the document is marked by a clear confusion concerning the use of terms such as 'peace operations' and 'peacekeeping operations'. More than an abstract academic quarrel, however, these definitions refer to different types of operations and demand different amounts of investment in terms of economic resources, time and personnel - the latter, in turn, needing specialised training for different operations. Maintaining such inconsistencies, therefore, may jeopardise Brazil's emergence as a great power after Luis Inácio Lula da Silva has left office.

\section{References}

Aguillar, Sérgio L. (2002). As Forças de Paz do Brasil: Balanço, in Clóvis Brigagão and Domício Proença Jr., Eds. Brasil e o Mundo: Novas Visōes. Rio de Janeiro: Livraria Francisco Alves, p. 363-439.

Aguillar, Sérgio L. Ed. (2005). Brasil em Missões de Paz. São Paulo: Usina do Livro.

Alsina Jr., João Paulo (2009). O Poder Militar como Instrumento da Política Externa Brasileira Contemporânea. Revista Brasileira de Política Internacional, Vol. 52, N. 2, pp. 173-191.

Amorim, Celso (1994). Pronunciamento do Ministro Celso Amorim na Reunião do Conselho de Segurança da ONU sobre a Situação no Haiti. Resenha de Politica Exterior do Brasil, Vol. 75, pp. 17-18.

Amorim, Celso (2004). Discurso Pronunciado pelo Ministro das Relaçōes Exteriores, Embaixador Celso Amorim, em Sessão do Conselho de Segurança das Naçôes Unidas sobre Aspectos Civis da Gestão de Conflitos e a Construção da Paz. 22 Sep 2004. New York. Published at [http://www. 
itamaraty.gov.br/sala-de-imprensa/notas-a-imprensa/2004/09/22/discurso-pronunciadopelo-ministro-das-relacoes/?searchterm=discurso $\% 20 \mathrm{Haiti} \% 20 \mathrm{justi} \% \mathrm{C} 3 \% \mathrm{~A} 7 \mathrm{a} \% 20$ social] . Available on: 10 May 2010.

Amorim, Celso (2006). Discurso do Ministro de Estado das Relaçôes Exteriores, Embaixador Celso Amorim, na Sessão de Abertura da Reunião de Alto Nivel sobre o Haiti. 23 Maio 2006. Brasília. Published at [http://www.defesanet.com.br/panoramahaiti/mre_23mai06.htm]. Available on: 9 May 2010.

Amorim, Celso (2007). Discurso do do Ministro de Estado das Relaçôes Exteriores, Embaixador Celso Amorim, por Ocasião da Abertura do "Seminário de Alto Nivel sobre Operaçôes de Manutenção da Paz”. 5 Feb 2007. Brasília. Published at [http://www.itamaraty.gov.br/sala-deimprensa/discursos-artigos-entrevistas-e-outras-comunicacoes/embaixador-celso-luiz-nunesamorim/discurso-do-do-ministro-de-estado-das-relacoes]. Available on: 11 May 2010.

Araújo Castro, João Augusto (1972). The United Nations and the Freezing of the International Power Structure. International Organization, Vol. 26, N. 1, pp. 158-166.

Barnett, Michael, Hunjoon Kim, Madalene O’Donnell and Laura Sitea (2007). Peacebuilding: What is in a Name? Global Governance, Vol. 13, N. 1, pp. 35-58.

Bellamy, Alex J., Paul Williams and Stuart Griffin (2004). Understanding Peacekeeping. Cambridge: Polity Press.

Bergman, Annika (2004). The Nordic Militaries: Forces for Good?, in Lorraine Elliott and Graeme Cheeseman, Eds. Forces for Good: Cosmopolitan Militaries in the Twenty-First Century. Manchester: Manchester University Press, pp. 168-186.

Bernal-Meza, Raúl (2002). A Política Exterior do Brasil: 1990-2002. Revista Brasileira de Política Internacional, Vol. 45, N. 1, pp. 36-71.

Brazil (1996). Política de Defesa Nacional. Brasília: Ministério da Defesa. Published at [http:// www.planalto.gov.br/publi_04/colecao/DEFES.htm]. Available on: 9 May 2010.

Brazil (2005). Politica de Defesa Nacional. Brasília: Ministry of Defence. Published at [https:// www.defesa.gov.br/pdn/decreto_politica_defesa_nacional.pdf]. Available on: 09 May 2010.

Brazil (2008). Estratégia Nacional de Defesa: Paz e Segurança para o Brasil. 2nd. Brasília: Ministry of Defence. Published at [https://www.defesa.gov.br/]. Available on: 9 May 2010.

Bullion, Alan (1997). India and UN Peacekeeping Operations. International Peacekeeping, Vol. 4, N. 1, pp. 98-114.

Burges, Sean W. (2008). Consensual Hegemony: Theorizing Brazilian Foreign Policy after the Cold War. International Relations, Vol. 22, N. 1, pp. 65-84.

Cardoso, Afonso José Sena (1998). O Brasil nas Operaçôes de Paz das Nações Unidas. Brasília: Instituto Rio Branco, Fundação Alexandre de Gusmão, Centro de Estudos Estratégicos, 168 pp.

Cervo, Amado Luiz (2002). A Dimensão da Segurança na Política Exterior do Brasil, in Clóvis Brigagão and Domício Proença Jr., Eds. Brasile o Mundo: Novas Visóes. Rio de Janeiro: Livraria Francisco Alves, pp. 319-361.

Cervo, Amado Luiz and Clodoaldo Bueno (2002). História da Política Exterior do Brasil. Brasília: Editora UnB, 525 pp.

Cousens, Elizabeth M. (2001). Introduction, in Elizabeth M. Cousens, Chetan Kumar and Karin Wermester, Eds. Peacebuilding as Politics: Cultivating Peace in Fragile Societies. Boulder: Lynne Rienner, pp. 1-20. 
da Silva, Luiz Inácio Lula (2004a). Discurso do Presidente da República, Luiz Inácio Lula da Silva, na Cerimônia de Embarque das Tropas Militares para Missão de Paz no Haiti, Base Aérea de Brasilia. Brasília. Published at [http://kitplone.itamaraty.gov.br/sala-de-imprensa/ discursos-artigos-entrevistas-e-outras-comunicacoes/presidente-da-republica-federativa-dobrasil/560382073724-discurso-do-presidente-da-republica-luiz-inacio]. Available on: 11 May 2010.

da Silva, Luiz Inácio Lula (2004b). Statement by H.E. Luiz Inácio Lula da Silva, President of the Federative Republic of Brazil, at the General Debate of the 59th Session of the General Assembly of the United Nations. New York: UNGA. Published at [http://www.un.org/webcast/ga/59/ statements/braeng040921.pdf]. Available on: 12 Sep 2008.

Diehl, Paul F. (2008). Peace Operations. Cambridge: Polity press, 197 pp.

Diehl, Paul F., Daniel Druckman and James Wall (1998). International Peacekeeping and Conflict Resolution: a Taxonomic Analysis with Implications. Journal of Conflict Resolution, Vol. 42, N. 1, pp. 33-55.

Diniz, Eugênio (2005). O Brasil e a Minustah. Security and Defense Studies Review, Vol. 5, N. 1, pp. 90-108.

Diniz, Eugênio (2006). O Brasil e as Operações de Paz, in Henrique Altemani de Oliveira and Antônio Carlos Lessa, Eds. Relações Internacionais do Brasil: Temas e Agendas. São Paulo: Saraiva, pp. 303-337.

DPKO (2003). UN Mission's Summary Detailed by Country, 31 Jan 2003, published at Department of Peacekeeping Operations [http://www.un.org/en/peacekeeping/contributors/ 2003/January2003_3.pdf]. Available on: 9 May 2010.

DPKO (2008). United Nations Peacekeeping Operations: Principles and Guidelines. New York: United Nations Department of Peacekeeping Operations. Published at [http://pbpu.unlb.org/ pbps/Library/Capstone_Doctrine_ENG.pdf]. Available on: 9 May 2010.

DPKO (2010a). UN Mission's Summary Detailed by Country, 31 May 2010, published at Department of Peacekeeping Operations [http://www.un.org/en/peacekeeping/contributors/ 2010/may10_3.pdf]. Available on: 2 Jun 2010.

DPKO (2010b). UN Peacekeeping [http://www.un.org/en/peacekeeping/]. Available on: 9 May 2010.

Durch, William J., Ed. (1993). The Evolution of UN Peacekeeping: Case Studies and Comparative Analysis. New York: St. Martin's Press.

Durch, William J Ed. (1996). UN Peacekeeping, American Politics, and the Uncivil Wars of the 1990s. New York: St. Martin's Press.

Fonseca Jr., Gelson (1998). A Legitimidade e Outras Questôes Internacionais. São Paulo: Paz e Terra.

Fontoura, Paulo Roberto Tarrisse da (2006). O Brasil e as Operaçôes de Manutenção da Paz das Naçôes Unidas. Brasília: FUNAG.

Fontoura, Paulo Roberto Tarrisse da (2009). Brasil: 60 Anos de Operaçôes de Paz. Rio de Janeiro: Departamento do Patrimônio Histórico e de Documentação da Marinha do Brasil.

Galtung, Johan (1969). Violence, Peace and Peace Research. Journal of Peace Research, Vol. 6, N. 3, pp. 167-191.

Gauthier, Amélie and Sarah John de Sousa (2006). Brasil en Haiti: El Debate Respecto a la Missión de Paz, Nov 2006, published at Fundación para las Relaciones Internacionales y el 
Diálogo Exterior (FRIDE) [http://www.fride.org/download/COM_BraHaiti_ESP_nov06. pdf]. Available on: 31 Mar 2009.

Gegout, Catherine (2009). The West, Realism and Intervention in the Democratic Republic of Congo (1996-2006). International Peacekeeping, Vol. 16, N. 2, pp. 231-244.

Gill, Bates and Chin-Hao Huang (2009). China's Expanding Role in Peacekeeping: Prospects and Policy Implications. SIPRI Policy Paper, Vol. 25.

Gonnet, Diego and Diego Hernández (2007). La Participación Uruguaya en las Misiones de Paz, Una Herramienta de Inserción Subestimada. Cuadernos del Claeh, Vol. 94-95, pp. 59-89.

Gratius, Susanne (2007). O Brasil nas Américas: Potência Regional Pacificadora?, published at FRIDE [http://www.fride.org/descarga/WP35_BraAmer_POR_abr07.pdf]. Available on: 4 Apr 2009.

Hirst, Mónica and Elsa Llenderrozas (2008). La Dimensión Politica de la Presencia en Haití: Los Desafíos para El $A B C+U$, published at FLACSO/Argentina, IDRC [http://www.haitiargentina. org/content/download/811/2896/file/PDF.pdf]. Available on: 9 May 2010.

Krishnasamy, Kabilan (2001). 'Recognition' for Third World Peacekeepers: India and Pakistan. International Peacekeeping, Vol. 8, N. 4, pp. 56-76.

Lannes, Ulisses Lisboa Perazzo. 1998. O Brasil e as Operações de Manutenção da Paz. In O Brasil e as Novas Dimensões da Segurança Internacional. São Paulo: Instituto de Estudos Avançados da Universidade de São Paulo.

Neack, Laura (1995). UN Peace-Keeping: In the Interest of Community or Self? Journal of Peace Research, Vol. 32, N. 2, pp. 181-196.

Rocha, Antônio Jorge Ramalho da (2009). Política Externa e Política de Defesa no Brasil: Civis e Militares, Prioridades e a Participação em Missões de Paz. e-cadernos ces, Vol. 6, pp. 142-158.

Seitenfus, Ricardo (2006a). Elementos para uma Diplomacia Solidária: a Crise Haitiana e os Desafios da Ordem Internacional Contemporânea. Carta Internacional, Vol. 1, N. 1, pp. 5-12.

Seitenfus, Ricardo (2006b). Um Exemplo de Diplomacia Solidária: o Brasil no Haiti, 9 May 2010, published at the author's personal website [http://www.seitenfus.com.br/arquivos/o_ brasil_no_haiti.pdf].

SIPRI (2010). SIPRI Multilateral Peace Operations Database [http://www.sipri.org/databases/ pko]. Available on: 9 May 2010.

Sorenson, David S. and Pia Christina Wood, Eds. (2005). The Politics of Peacekeeping in the Post-Cold War Era. London: Frank Cass, 219 pp.

Staley, Robert Stephens II (1992). The Wave of the Future: The United Nations and Naval Peacekeeping. Boulder: Lynne Rienner.

UN (2008). United Nations Peacekeeping Operations: Principles and Guidelines. New York: United Nations. Published at [http://pbpu.unlb.org/pbps/Library/Capstone_Doctrine_ENG. pdf]. Available on: 11 Nov 2008.

UNSC (1993). Provisional Verbatim Record of the 3282nd Meeting. 23 Sep 1993. S/PV.3282. New York: United Nations Security Council.

UNSC (1994a). Provisional Verbatim Record of the 3352nd Meeting. 23 Mar 1994. S/PV.3352. New York: United Nations Security Council. 
UNSC (1994b). Provisional Verbatim Record of the 3397th Meeting. 30 Jun 1994. S/PV.3397. New York: United Nations Security Council.

UNSC (1994c). Provisional Verbatim Record of the 3413rd Meeting. 31 Jul 1994. S/PV.3413. New York: United Nations Security Council.

UNSC (1994d). Resolution 940, Adopted by the Security Council at Its 3413th Meeting, on 31 July 1994. S/RES/940. New York: United Nations Security Council.

UNSC (2004). Provisional Verbatim Record of the 4919th Meeting. 29 Feb 2004. S/PV.4919. New York: United Nations Security Council.

Vigevani, Tullo and Gabriel Cepaluni (2007). A Política Externa de Lula da Silva: a Estratégia da Autonomia pela Diversificação. Contexto Internacional, Vol. 29, N. 2, pp. 273-335.

Vigevani, Tullo, Marcelo F. de Oliveira and Rodrigo Cintra (2003). Política Externa no Período FHC: a Busca de Autonomia pela Integração. Tempo Social, Vol. 15, N. 2, pp. 31-61.

Viola, Eduardo (2005). Transformaçôes na Posição do Brasil no Sistema Internacional, 19902005. Plenarium, Vol. 2, N. 2, pp. 94-120.

Wrobel, Paulo and Mônica Herz (2002). A Política Brasileira de Segurança no Pós-Guerra Fria, in Clóvis Brigagão and Domício Proença Jr., Eds. Brasil e o Mundo: Novas Visóes. Rio de Janeiro: Livraria Francisco Alves, pp. 255-318.

Zaverucha, Jorge (2005). A Fragilidade do Ministério da Defesa Brasileiro. Revista de Sociologia e Política, N. 25, pp. 107-121.

Received September 25, 2010

Accepted November 18, 2010

\section{Abstract}

The article analyses how Brazilian state actions and policies regarding peace operations during the Presidency of Lula da Silva relate to the country's positions and attitudes towards United Nations peacekeeping. It argues that the inconsistencies identified on the Brazilian positions reflect the lack of a clear strategic horizon guiding the country's participation in UN peacekeeping, which consequentially hinders the country emergence as a great power.

\section{Resumo}

O artigo analisa como ações e políticas de Estado no que respeita operações de paz durante a Presidência de Lula da Silva relacionam-se com as posições e atitudes do Brasil em relação às operações de manutenção da paz das Nações Unidas. Argumenta que as inconsistências identificadas nas posições brasileiras refletem a falta de um horizonte estratégico que oriente a participação do país em operações de manutenção da paz da ONU, o que conseqüentemente, pode prejudicar a emergência do país como grande potência.

Keywords: Brazilian foreign policy, Lula da Silva; peacekeeping.

Palavras-chave: Política Externa Brasileira, Governo Lula da Silva; manutenção da paz. 